\title{
Penentu Kebijakan Dividen Perusahaan yang Sahamnya Masuk dalam Daftar Efek Syariah
}

\author{
Moh Khoiruddin \\ Fakultas Ekonomi Universitas Negeri Semarang, Indonesia \\ Email: mohkhoiruddin@yahoo.co.id \\ Yuni Setiowati \\ Fakultas Ekonomi Universitas Negeri Semarang, Indonesia \\ Email : yuni_more@yahoo.com
}

\begin{abstract}
This study purpose to the determine the influence of Current Ratio, Debt to Equity Ratio, Earning Per Share, and Return On Assets to the Dividend Policy (Dividend Payout Ratio) for companies included Daftar Efek Syariah period 2008-2010 simultaneously and partial. The population in this study all companies included Daftar Efek Syariah period 2008-2010 amount to 286 companies. The sample selection procedure used was a purposive sampling so that it produced 44 companies. Secondary data was collected by the documentation technique were obtained from the fundamental annual report 2011. The analysis technique used was multiple linear regression analysis using the tools of SPSS. The research found that four variables of kind of CR, DER, EPS and ROA simultaneously influence to DPR for companies included Daftar Efek Syariah period 2008-2010. The three variables of kind of CR, EPS, and ROA partially influence positive significant to DPR, while variable DER influence negative but insignificant to DPR for companies included Daftar Efek Syariah period 2008-2010.
\end{abstract}

Keywords: Dividend Payout Ratio, Efek Syariah

\footnotetext{
Abstrak

Penelitian ini bertujuan menguji pengaruh Current Ratio, Debt to Equity Ratio, Earning Per Share, dan Return On Assets terhadap Kebijakan Dividen (Dividend Payout Ratio) pada perusahaan yang termasuk dalam Daftar Efek Syariah periode 2008-2010 secara simultan dan parsial. Populasi dalam penelitian
} 
ini seluruh perusahaan yang masuk dalam Daftar Efek Syariah sebanyak 286 perusahaan. Sampel diambil menggunakan purposive sampling sehingga menghasilkan 44 perusahaan. Data sekunder dikumpulkan dengan teknik dokumentasi bersumber dari ringkasan kinerja keuangan tahun 2011. Teknik analisis yang digunakan dalam penelitian ini adalah analisis regresi linier berganda menggunakan alat bantu SPSS. Hasil penelitian ini secara simultan variabel CR, DER, EPS dan ROA berpengaruh terhadap DPR pada perusahaan yang termasuk dalam DES periode 2008-2010. Secara parsial variabel CR, EPS dan ROA berpengaruh positif signifikan terhadap DPR, sedangkan variabel DER berpengaruh negatif tidak signifikan terhadap DPR pada perusahaan yang termasuk dalam DES periode 2008-2010.

\section{Kata Kunci: Dividend Payout Ratio, Efek Syariah}

\section{Pendahuluan}

Dividen merupakan bagian yang tidak dapat dipisahkan dengan keputusan pendanaan dan keputusan investasi perusahaan. Dua teori kebijakan dividen yang dominan adalah signaling theory (misalnya Bhattacharya (1979), John dan Williams (1985), Miller dan Rock (1985), dan Ofer dan Thakor (1987)) dan aliran kas bebas/free cashflow theory (misalnya Easterbrook (1984), Jensen (1986), dan Lang dan Litzenberger (1989)). Jika sinyal informasi dividen eksklusif manajemen sampai kepada pemegang saham, maka peningkatan dividen tak terduga menyebabkan apresiasi harga saham yang abnormal. Jika dividen mengurangi inefisiensi arus kas bebas, maka peningkatan dividen akan meningkatkan nilai perusahaan melalui pengurangan kelebihan uang tunai. Dengan demikian, kedua teori tersebut memprediksi bahwa kenaikan tak terduga dividen menghasilkan reaksi harga positif, yang secara empiris telah terdukung. Apabila manajemen perusahaan memutuskan untuk membayar dividen, maka jumlah laba yang ditahan akan berkurang, dan jika manajemen memutuskan tidak membayar dividen, maka akan meningkatkan pendanaan dari sumber dana internal. Hal ini yang menyebabkan kebijakan dividen sampai saat ini terus 
menjadi perdebatan terutama pada saat kebijakan dividen dihubungkan dengan nilai perusahaan.

Daftar Efek Syariah (DES) merupakan kumpulan efek yang tidak bertentangan dengan prinsip-prinsip syariah di Pasar Modal, yang ditetapkan oleh Bapepam-LK atau pihak yang disetujui Bapepam-LK. Kriteria terbaru saham yang masuk dalam DES didasarkan pada peraturan Bapepam-LK Nomor II.K1 pasal 1.b.7 tahun 2009 yaitu perusahaan tidak melakukan kegiatan usaha yang bertentangan dengan prinsip syariah, seperti usaha perjudian, jasa keuangan ribawi (bank dan asuransi konvensional), barang haram (miras), dan barang mudarat (rokok). Tidak melakukan transaksi yang mengandung unsur suap dan memenuhi rasio keuangan yaitu total hutang yang berbasis bunga dibandingkan dengan total aset tidak lebih dari $82 \%$, serta total pendapatan yang berbasis bunga dan pendapatan tidak halal lainnya dibandingkan dengan total pendapatan usaha dan pendapatan lain-lain tidak lebih dari $10 \%$.

Kebijakan dividen perusahaan tercermin pada dividend payout ratio yaitu presentase laba yang dibagikan dalam bentuk dividen tunai. Hal ini berarti besar kecilya dividend payout ratio akan mempengaruhi keputusan investasi para pemegang saham dan di sisi lain berpengaruh pada kondisi keuangan perusahaan (Marlina dan Danica, 2009). Sementara, Modigliani dan Miller mengatakan bahwa kebijakan dividen sebuah perusahaan tidak berpengaruh pada nilai maupun biaya modal.

Rasio likuiditas suatu perusahaan merupakan faktor penting yang harus dipertimbangkan sebelum mengambil keputusan penetapan besarnya dividen yang akan dibayarkan kepada pemegang saham (Riyanto, 2001). Rasio yang digunakan adalah Current Ratio, semakin kuat tingkat likuiditas perusahaan semakin besar kemampuan perusahaan dalam memenuhi kewajiban jangka pendek. Perusahaan yang memiliki likuiditas baik maka kemampuan untuk membayar dividen juga baik. Teori ini didukung hasil penelitian Anil dan Kapoor (2008), dan Wahdah (2011) yang menyatakan bahwa Current Ratio berpengaruh positif terhadap Dividend Payout Ratio.

Debt to Equity Ratio merupakan rasio yang mengukur seberapa jauh perusahaan dibiayai oleh utang (Sartono, 2001). Penggunaan utang sebagai 
sumber pendanaan akan menyebabkan perusahaan harus menanggung beban tetap berupa pembayaran bunga dan pokok pinjaman, sehingga semakin tinggi Debt to Equity Ratio maka semakin kecil dividen yang dibagikan kepada pemegang saham karena kewajiban membayar utang lebih diutamakan daripada pembagian dividen. Teori ini didukung hasil penelitian Masdupi (2012) dan Wira (2010) yang menyatakan bahwa Debt to Equity Ratio berpengaruh negatif terhadap Dividend Payout Ratio.

Earning Per Share (EPS) merupakan tingkat keuntungan bersih yang akan diraih perusahaan pada saat menjalankan operasi (Riyanto, 2001). Keuntungan yang layak dibagikan sebagai dividen adalah keuntungan setelah perusahaan memenuhi seluruh kewajiban bunga dan pajak. Bila perusahaan mempunyai tingkat profitabilitas yang tinggi, maka laba yang diperoleh perusahaan juga tinggi, sehingg laba yang dibagikan kepada pemegang saham semakin besar. Semakin besar laba yang tersedia bagi pemegang saham, maka pembayaran dividen kepada pemegang saham juga semakin besar. Teori ini didukung hasil penelitian Darminto (2008), dan Imran (2011), yang menyatakan bahwa EPS berpengaruh positif terhadap Dividend Payout Ratio.

Return On Assets (ROA) menunjukkan kemampuan modal yang diinvestasikan dalam total aktiva untuk menghasilkan laba perusahaan (Sartono, 2001). Semakin tinggi ROA maka kemungkinan pembagian dividen juga semakin banyak. Penjelasan teoritis tersebut didukung hasil penelitian Marlina dan Danica (2009), Pribadi dan Sampurno (2012) yang menyatakan bahwa Return On Assets berpengaruh positif terhadap Dividend Payout Ratio.

Berdasarkan hasil sejumlah penelitian sebelumnya dan teori yang melandasi kebijakan dividen sebagaimana dipaparkan di atas, terlihat masih belum ada kesimpulan final mengenai faktor-faktor yang mempengaruhi kebijakan dividen yang dilakukan perusahaan. Demikian pula untuk perusahaanperusahaan yang sahamnya masuk dalam kategori syariah, karena masih sedemikian terbatasnya literatur dan riset pada wilayah ini. Penelitian ini mencoba berkontribusi untuk mengetahui faktor keuangan apa saja yang menentukan kebijakan dividen perusahaan yang mempunyai karakteristik khusus, yaitu yang sahamnya masuk dalam Daftar Efek Syariah. 


\section{Rumusan Masalah}

Berdasarkan uraian latar belakang masalah di atas, maka rumusan masalah dalam penelitian ini adalah: 1) Apakah Current Ratio (CR), Debt to Equity Ratio (DER), Earning Per Share (EPS), dan Return on Assets (ROA) secara parsial berpengaruh terhadap kebijakan dividen pada perusahaan yang sahamnya termasuk dalam Daftar Efek Syaria; 2) Apakah Current Ratio (CR), Debt to Equity Ratio (DER), Earning Per Share (EPS), dan Return on Assets (ROA) secara simultan berpengaruh terhadap kebijakan dividen pada perusahaan yang sahamnya termasuk dalam Daftar Efek Syariah.

\section{Tujuan dan Kontribusi Penelitian}

Penelitian ini bertujuan untuk mengetahui pengaruh Current Ratio (CR), Debt Equity Ratio (DER), Earning Per Share (EPS), dan Return On Assets (ROA) secara parsial terhadap kebijakan dividen pada perusahaan yang sahamnya termasuk dalam Daftar Efek Syariah.

Selain itu penelitian ini juga untuk mengetahui pengaruh Current Ratio (CR), Debt Equity Ratio (DER), Earning Per Share (EPS), dan Return On Assets (ROA) secara simultan terhadap kebijakan dividen pada perusahaan yang sahamnya termasuk dalam Daftar Efek Syariah.

Hasil penelitian ini akan memberikan kontribusi, baik pada aspek teoritis maupun praktis. Pada aspek teoritis, penelitian ini bisa memberikan sumbangan hasil penelitian empiris mengenai faktor-faktor yang dapat mempengaruhi kebijakan dividen yang dalam hal ini diproksi dengan Dividend Payout Ratio (DPR) secara khusus dalam perusahaan yang sahamnya masuk dalam daftar efek syariah, sehingga menambah pengetahuan lebih tentang kebijakan dividen perusahaan yang selama ini didominasi hasil penelitian dari perusahaanperusahaan konvensional.

Manfaat Praktis bagi perusahaan, penelitian ini dapat dijadikan dasar pertimbangan pengambilan keputusan oleh manajemen perusahaan dalam menentukan Dividen Payout Ratio yang akan dibagikan. Bagi investor, penelitian ini sebagai masukan dalam mempertimbangkan pengambilan keputusan investasi 
pada perusahaan yang sahamnya masuk Daftar Efek Syariah, sehubungan harapan terhadap pendapatan dividen.

\section{Studi Pustaka dan Kerangka Teoritik}

Anil dan Kapoor (2008:68) menguji Determinants of Dividend Payout Ratios-A Study of Indian Information Technology Sector. Hasil penelitian menunjukkan bahwa liquidity berpengaruh signifikan terhadap dividend payout ratio, sedangkan profitability, corporate tax, sales growth dan MTBV (market to book value) tidak berpengaruh signifikan terhadap dividend payout ratio.

Arilaha (2009:85-86) menguji pengaruh Free Cash Flow, Profitabilitas,

Likuiditas dan Leverage terhadap Kebijakan Dividen. Hasil penelitian menunjukkan bahwa Profitabilitas mempunyai pengaruh signifikan terhadap kebijakan dividen, sedangkan Free Cash Flow, Likuiditas dan Leverage tidak berpengaruh secara signifikan terhadap kebijakan dividen.

Darminto (2008:96) menguji pengaruh profitabilitas, likuiditas, dan struktur kepemilikan saham terhadap kebijakan dividen pada perusahaan manufaktur yang terdaftar pada Bursa Efek Indonesia periode 2002-2005. Hasil penelitian menunjukkan bahwa profitabilitas dan struktur modal berpengaruh signifikan terhadap kebijakan dividen, sedangkan likuiditas dan struktur kepemilikan saham tidak berpengaruh signifikan terhadap kebijakan dividen.

Imran (2011:56) menguji Determinants of Dividend Payout Policy “A case of Pakistan Engineering Sector". Hasil penelitian menunjukkan bahwa Return On Assets, Firm Size, Growth dan Earning Per Share berpengaruh signifikan terhadap Dividend Payout Ratio, sedangkan Cash Position berpengaruh negatif tidak signifikan terhadap Dividend Payout Ratio.

Marlina dan Danica (2009:5) menguji pengaruh Cash Position, Debt Equity Ratio, dan Return On Assets terhadap Dividend Payout Ratio pada 24 
perusahaan manufaktur yang terdaftar di Bursa Efek Indonesia periode Januari 2004 - Desember 2007. Hasil penelitian menunjukkan bahwa Cash Position, dan $R O A$ mempunyai pengaruh positif signifikan terhadap $D P R$, sedangkan $D E R$ tidak mempunyai pengaruh yang signifikan terhadap $D P R$.

Masdupi (2012:6-7) menguji pengaruh Insider Ownership, Struktur Modal, dan Pertumbuhan Perusahaan terhadap Kebijakan Dividen Perusahaan Syariah yang terdaftar di BEI periode 2007-2009. Hasil penelitian menunjukkan Struktur Modal (DER), dan Pertumbuhan Perusahaan berpengaruh signifikan terhadap Dividend Payout Ratio, sedangkan Insider Ownership berpengaruh negatif tidak signifikan terhadap Dividend Payout Ratio.

Pribadi dan Sampurno (2012:7-8) menganalisis pengaruh Cash Position, Firm Size, Growth Opportunity, Ownership dan Return On Assets terhadap Dividend Payout Ratio. Hasil penelitian menunjukkan bahwa ROA, Ownership berpengaruh positif signifikan terhadap DPR, Cash Position dan Firm Size berpengaruh negatif signifikan terhadap DPR, sedangkan Growth Opportunity berpengaruh negatif tidak signifikan terhadap DPR.

Sumiadji (2011:136) menguji analisis variabel keuangan yang mempengaruhi kebijakan dividen pada 8 perusahaan manufaktur yang terdaftar di Bursa Efek Indonesia periode 2004-2008. Hasil penelitian menunjukkan Cash Ratio, Earning Per Share, dan TATO berpengaruh terhadap Dividend Payout Ratio, sedangkan Return On Assets, dan Debt Equity Ratio tidak berpengaruh terhadap Dividend Payout Ratio.

Wahdah (2011:318-319) menganalisis faktor yang mempengaruhi tingkat pengembalian investasi pada perusahaan manufaktur di Bursa Efek Indonesia 
periode 2006-2008. Hasil penelitian menunjukkan bahwa Return on Investment,

Current Ratio, Asset Turnofer mempunyai pengaruh signifikan terhadap Dividend

Payout Ratio, sedangkan Debt Equity Ratio tidak berpengaruh signifikan terhadap

Dividend Payout Ratio.

Wira (2010:97) menguji faktor yang mempengaruhi pengembalian investasi pada Equity Securities pada perusahaan manufaktur di Indonesia. Hasil penelitian menunjukkan bahwa profitabilitas dan leverage berpengaruh secara signifikan terhadap dividen, sedangkan likuiditas, growth dan firm size tidak berpengaruh secara signifikan terhadap dividen. Ringkasan penelitian terdahulu dapat dilihat pada Tabel 1 .

Tabel 1 Ringkasan Hasil Penelitian Terdahulu

\begin{tabular}{|c|c|c|c|}
\hline No & $\begin{array}{c}\text { Peneliti dan } \\
\text { Tahun }\end{array}$ & Variabel dan Sampel & Hasil Penelitian \\
\hline 1 & $\begin{array}{l}\text { Anil dan } \\
\text { Kapoor (2008) }\end{array}$ & $\begin{array}{l}\text { - Liquidity, profitability, } \\
\text { corporate tax, sales } \\
\text { growth dan MTBV } \\
\text { terhadap dividend payout } \\
\text { ratio } \\
\text { - A Study of Indian } \\
\text { Information Technology } \\
\text { Sector } \\
\end{array}$ & $\begin{array}{l}\text { - Liquidity berpengaruh signifikan } \\
\text { terhadap dividend payout ratio } \\
\text { - Profitability, corporate tax, sales } \\
\text { growth dan } M T B V \text { berpengaruh } \\
\text { tidak signifikan terhadap dividend } \\
\text { payout ratio. }\end{array}$ \\
\hline 2 & Arilaha (2009) & $\begin{array}{l}\text { - Free Cash Low, } \\
\text { Profitabilitas, Likuiditas } \\
\text { dan Leverage terhadap } \\
\text { kebijakan dividen } \\
\text { - Perusahaan manufaktur di } \\
\text { BEI periode 2004-2007 }\end{array}$ & $\begin{array}{l}\text { - Profitabilitas berpengaruh } \\
\text { signifikan terhadap kebijakan } \\
\text { dividen } \\
\text { - Free Cash Flow, Likuiditas dan } \\
\text { Leverage tidak berpengaruh } \\
\text { signifikan terhadap kebijakan } \\
\text { dividen }\end{array}$ \\
\hline 3 & $\begin{array}{l}\text { Darminto } \\
(2008)\end{array}$ & $\begin{array}{l}\text { - Profitabilitas, Likuiditas, } \\
\text { Struktur Modal dan } \\
\text { Struktur Kepemilikan } \\
\text { Saham terhadap Kebijakan } \\
\text { Dividen } \\
\text { - Perusahaan manufaktur } \\
\text { yang terdaftar di BEI } \\
\text { periode 2002-2005 }\end{array}$ & $\begin{array}{l}\text { - Profitabilitas dan Struktur Modal } \\
\text { berpengaruh signifikan terhadap } \\
\text { kebijakan dividen } \\
\text { - Likuiditas dan Struktur } \\
\text { Kepemilikan Saham berpengaruh } \\
\text { tidak signifikan terhadap } \\
\text { kebijakan dividen }\end{array}$ \\
\hline 4 & Imran (2011) & $\begin{array}{l}\text { - ROA, Cash Position, EPS, } \\
\text { Firm Size, dan Growth } \\
\text { terhadap DPR } \\
\text { - A Case of Pakistan } \\
\end{array}$ & $\begin{array}{l}\text { - ROA, EPS, Firm Size, dan Growth } \\
\text { berpengaruh positif signifikan } \\
\text { terhadap DPR } \\
\text { - CP berpengaruh negatif tidak }\end{array}$ \\
\hline
\end{tabular}




\begin{tabular}{|c|c|c|c|}
\hline & & Engineering Sector & signifikan terhadap DPR \\
\hline 5 & $\begin{array}{l}\text { Marlina dan } \\
\text { Danica (2009) }\end{array}$ & $\begin{array}{l}\text { - ROA, Cash Position, dan } \\
\text { DER terhadap DPR } \\
\text { - Perusahaan manufaktur } \\
\text { yang terdaftar di BEI } \\
\text { periode Januari } 2004 \text { - } \\
\text { Desember } 2007\end{array}$ & $\begin{array}{l}\text { - ROA dan CP berpengaruh positif } \\
\text { signifikan terhadap DPR } \\
\text { - DER berpengaruh positif tidak } \\
\text { signifikan terhadap DPR }\end{array}$ \\
\hline 6 & $\begin{array}{l}\text { Masdupi } \\
(2012)\end{array}$ & $\begin{array}{l}\text { - Insider Ownership, } \\
\text { Struktur Modal (DER), } \\
\text { dan growth terhadap DPR } \\
\text { - Perusahaan syariah yang } \\
\text { terdaftar di BEI }\end{array}$ & $\begin{array}{l}\text { - Struktur Modal (DER), dan } \\
\text { growth berpengaruh signifikan } \\
\text { terhadap DPR } \\
\text { - Insider Ownership berpengaruh } \\
\text { negatif tidak signifikan }\end{array}$ \\
\hline 7 & $\begin{array}{l}\text { Pribadi dan } \\
\text { Sampurno } \\
(2012)\end{array}$ & $\begin{array}{l}\text { - Cash Position, Firm Size, } \\
\text { Growth Opportunity, } \\
\text { Ownership, dan ROA } \\
\text { terhadap DPR } \\
\text { - Perusahaan manufaktur } \\
\text { yang terdaftar di BEI } \\
\text { periode 2008-2011 }\end{array}$ & $\begin{array}{l}\text { ROA, Ownership berpengaruh } \\
\text { positif signifikan terhadap DPR, } \\
\text { Cash Position dan Firm Size } \\
\text { berpengaruh negatif signifikan } \\
\text { terhadap DPR } \\
\text { - Growth Opportunity berpengaruh } \\
\text { negatif tidak signifikan terhadap } \\
\text { DPR }\end{array}$ \\
\hline 8 & $\begin{array}{l}\text { Sumiadji } \\
(2011)\end{array}$ & $\begin{array}{l}\text { - ROA, CR, DER, EPS, dan } \\
\text { TATO terhadap DPR } \\
\text { - Perusahaan manufaktur } \\
\text { yang terdaftar di BEI } \\
\text { periode 2004-2008 }\end{array}$ & $\begin{array}{l}\text { - CR, EPS, dan TATO berpengaruh } \\
\text { signifikan terhadap DPR } \\
\text { - ROA dan DER berpengaruh tidak } \\
\text { signifikan terhadap DPR }\end{array}$ \\
\hline 9 & Wahdah (2011) & $\begin{array}{l}\text { - ROI, Current Ratio, DER, } \\
\text { dan ATO terhadap DPR } \\
\text { - Perusahaan manufaktur di } \\
\text { BEI periode 2006-2008 }\end{array}$ & $\begin{array}{l}\text { - ROI, CR, dan ATO berpengaruh } \\
\text { positif signifikan terhadap DPR } \\
\text { - DER berpengaruh negatif tidak } \\
\text { signifikan terhadap DPR }\end{array}$ \\
\hline 10 & Wira (2010) & $\begin{array}{l}\text { - Profitabilitas, Likuiditas, } \\
\text { Leverage, Growth dan } \\
\text { Firm Size terhadap } \\
\text { dividen } \\
\text { - Perusahaan manufaktur di } \\
\text { BEI periode } 2000-2007\end{array}$ & $\begin{array}{l}\text { - Profitabilitas dan Leverage } \\
\text { berpengaruh signifikan terhadap } \\
\text { dividen } \\
\text { - Likuiditas, Growth dan Firm Size } \\
\text { berpengaruh tidak signifikan } \\
\text { terhadap dividen }\end{array}$ \\
\hline
\end{tabular}

Sumber : Data yang sudah diolah

\section{Kerangka Teoritik}

Current ratio merupakan salah satu ukuran dari rasio likuiditas yang dihitung dengan membagi aset lancar dengan utang lancar. Semakin besar current ratio menunjukkan semakin tinggi perusahaan dalam memenuhi kewajiban jangka pendek, sehingga kemampuan perusahaan dalam membagikan dividen juga semakin besar. Hal tersebut dapat dikatakan bahwa current ratio memiliki pengaruh yang positif terhadap dividend payout ratio. Pernyataan ini didukung 
penelitian terdahulu oleh Anil dan Kapoor (2008:68), dan Wahdah (2011:319) yang menyatakan bahwa Current Ratio berpengaruh positif signifikan terhadap Dividend Payout Ratio.

Debt to Equity Ratio merupakan kemampuan perusahaan dalam memenuhi seluruh kewajiban, semakin rendah DER maka semakin tinggi kemampuan perusahaan dalam membayar seluruh utang. Peningkatan utang akan mempengaruhi keuntungan bersih yang dibagikan kepada pemegang saham dalam bentuk dividen karena perusahaan lebih mengutamakan membayar utang terlebih dahulu. Hal tersebut dapat dikatakan bahwa debt to equity ratio memiliki pengaruh negatif terhadap dividend payout ratio. Pernyataan ini didukung penelitian terdahulu oleh Wira (2010:96) dan Masdupi (2012:6) yang menyatakan bahwa Debt to Equity Ratio berpengaruh negatif signifikan terhadap Dividend Payout Ratio.

Earning Per Share merupakan rasio profitabilitas yang tercermin pada setiap lembar saham yang beredar. Rasio profitabilitas merupakan bagian dari rasio fundamental, sehingga semakin tinggi profitabilitas perusahaan maka semakin tinggi pula keuntungan perusahaan yang dibagikan kepada pemegang saham dalam bentuk dividen atau dapat dikatakan bahwa EPS memiliki pengaruh positif terhadap dividend payout ratio. Pernyataan ini didukung penelitian terdahulu oleh Darminto (2008:96), dan Imran (2011:55) yang menyatakan bahwa Earning Per Share berpengaruh positif signifikan terhadap Dividend Payout Ratio.

Return on Assets merupakan tingkat pengembalian investasi atas investasi perusahaan pada aktiva tetap yang digunakan untuk operasi. ROA yang semakin 
besar menunjukkan kinerja perusahaan yang semakin baik, karena tingkat pengembalian investasi juga semakin besar. Return yang diterima investor berupa pendapatan dividen dan capital gain, sehingga dapat dikatakan bahwa ROA memiliki pengaruh positif terhadap dividend payout ratio. Pernyataan ini didukung penelitian terdahulu oleh Marlina dan Danica (2009:6), dan Pribadi dan Sampurno (2012:8) yang menyatakan bahwa Return on Assets berpengaruh positif signifikan terhadap Dividend Payout Ratio. Berikut ini adalah kerangka berfikir yang disajikan dalam bentuk gambar 2.1.

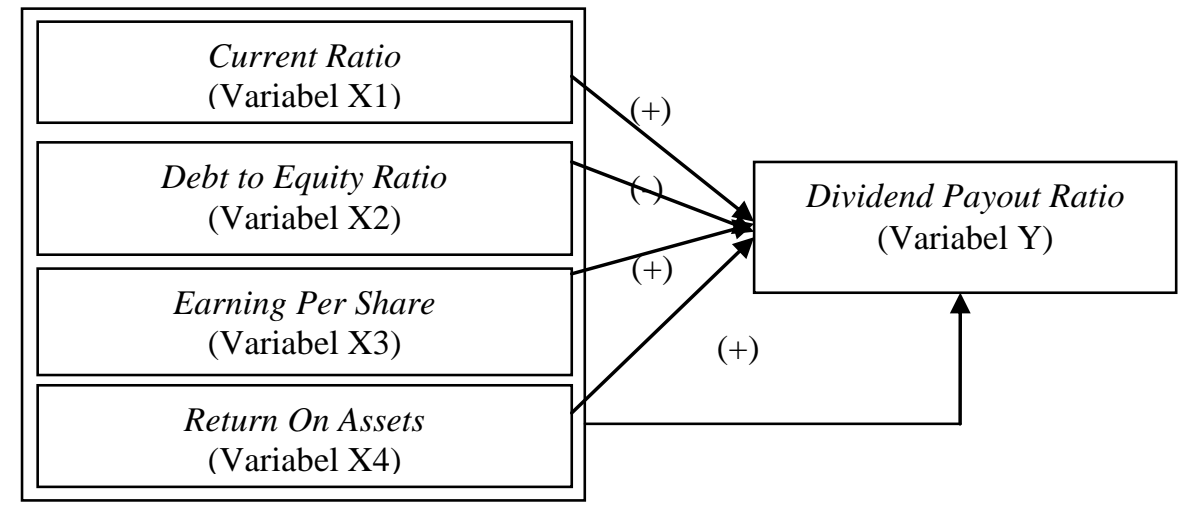

Gambar 2.1 Kerangka Berfikir

\section{Metode}

Jenis data yang digunakan dalam penelitian ini adalah data sekunder yang dikumpulkan melalui metode dokumentasi. Data diperoleh dari Ringkasan Kinerja Keuangan yang diterbitkan BEI tahun 2011. Populasi dalam penelitian ini adalah seluruh perusahaan yang sahamnya termasuk dalam Daftar Efek Syariah periode 2008-2010 sejumlah 286 perusahaan. Pengambilan sampel dalam penelitian ini dilakukan dengan metode purposive sampling dengan kriteria sebagai berikut: 1) perusahaan yang listing dalam DES periode 2008-2010, 2) perusahaan yang memiliki data laporan keuangan lengkap selama periode 20082010, 3) perusahaan yang selalu membagikan dividen selama periode 2008-2010, 4) perusahaan yang mempunyai Earning Per Share di atas Rp 10, sebagai batas 
under EPS selama periode 2008-2010. Berdasarkan kriteria tersebut, maka diperoleh sampel sebanyak 44 perusahaan.

Metode analisis yang digunakan adalah analisis regresi linier berganda. Sebelum melakukan analisis regresi linier berganda terlebih dahulu dilakukan uji normalitas data dan uji asumsi klasik (uji multikolinearitas, uji heterokedastisitas dan uji autokorelasi). Persamaan regresi linier berganda yang digunakan dalam penelitian ini adalah:

$Y=a+b_{1} X_{1}+b_{2} X_{2}+b_{3} X_{3}+b_{4} X_{4}$

Keterangan:

$\mathrm{Y} \quad=$ Dividend Payout Ratio (DPR)

A $\quad=$ Konstanta

$\mathrm{X}_{1}=$ Current Ratio $(\mathrm{CR})$

$\mathrm{X}_{2}=$ Debt to Equity Ratio $(D E R)$

$\mathrm{X}_{3} \quad=$ Earning Per Share $($ EPS $)$

$\mathrm{X}_{4} \quad=$ Return On Assets (ROA)

$\mathrm{b}_{1,2,3,4}=$ Koefisien Regresi variabel $\mathrm{X}_{1,2,3,4}$

Pengujian hipotesis menggunakan uji $\mathrm{F}$, uji $\mathrm{t}$ dan koefisien determinasi parsial $\left(\mathrm{r}^{2}\right)$. Uji F digunakan untuk menguji pengaruh variabel CR, DER, EPS dan ROA terhadap variabel DPR secara simultan. Uji t digunakan untuk menguji pengaruh variabel CR, DER, EPS dan ROA terhadap variabel DPR secara parsial. Koefisien determinasi parsial $\left(\mathrm{r}^{2}\right)$ digunakan untuk mengukur seberapa jauh variabel CR, DER, EPS, dan ROA dalam menerangkan variasi variabel DPR.

\section{Pembahasan dan Temuan}

Data sebelum diolah dilakukan Uji Normalitas terlebih dahulu. Berdasarkan Tabel 1 diketahui bahwa nilai Asymp Sig (2-tailed) 0,353>0,05, dengan tingkat kesalahan $(\alpha=5 \%)$ maka data tersebut berdistribusi normal.

Tabel 1 One-Sample Kolmogorov-Smirnov Test

\begin{tabular}{|c|c|c|}
\hline & & Unstandardized Residual \\
\hline $\begin{array}{l}\mathrm{N} \\
\text { Normal } \\
\text { Parameters }^{\mathrm{a}} \\
\text { Most Extreme } \\
\text { Differences }\end{array}$ & $\begin{array}{l}\text { Mean } \\
\text { Std. Deviation } \\
\text { Absolute } \\
\text { Positive }\end{array}$ & $\begin{array}{r}132 \\
.0000000 \\
17.92952087 \\
.081 \\
.081\end{array}$ \\
\hline
\end{tabular}




\begin{tabular}{|l|r|}
\multicolumn{1}{|c|}{ Negative } & -.039 \\
Kolmogorov-Smirnov Z & .930 \\
Asymp. Sig. (2-tailed) & .353 \\
\hline a. Test distribution is Normal.
\end{tabular}

Hasil Uji Multikolinearitas terlihat dalam Tabel 2. Berdasarkan Tabel 2 nilai tolerance $>0,1$ dan nilai VIF $<10$, dapat disimpulkan bahwa tidak terjadi multikolinieritas antar variabel bebas dalam model regresi ini.

Tabel 2 Coefficients ${ }^{a}$

\begin{tabular}{|c|c|c|c|c|c|c|c|}
\hline \multirow[b]{2}{*}{ Model } & \multicolumn{2}{|c|}{$\begin{array}{c}\text { Unstandardized } \\
\text { Coefficients }\end{array}$} & \multirow{2}{*}{$\begin{array}{c}\begin{array}{c}\text { Standardized } \\
\text { Coefficients }\end{array} \\
\text { Beta }\end{array}$} & \multirow[b]{2}{*}{$t$} & \multirow[b]{2}{*}{ Sig. } & \multicolumn{2}{|c|}{ Collinearity Statistics } \\
\hline & $B$ & Std. Error & & & & Tolerance & VIF \\
\hline 1 (Constant) & 7.664 & 7.763 & & .987 & .325 & & \\
\hline $\mathrm{CR}$ & .052 & .011 & .374 & 4.634 & .000 & .836 & 1.196 \\
\hline DER & -.147 & 2.223 & -.005 & -.066 & .947 & .857 & 1.166 \\
\hline Log_EPS & 6.644 & 3.044 & .180 & 2.183 & .031 & .806 & 1.241 \\
\hline ROA & .349 & .164 & .182 & 2.126 & .035 & .743 & 1.345 \\
\hline
\end{tabular}

Hasil Uji Heterokedastisitas ditampilkan dalam Tabel 3. Berdasarkan tabel di atas menunjukkan variabel CR, DER, Log EPS, dan ROA mempunyai nilai sig $\geq 0,05$, sehingga tidak ada variabel independen yang signifikan secara statistik mempengaruhi variabel DPR abs_res. Hal ini terlihat dari nilai sig pada variabel CR, DER, Log EPS, dan ROA seluruhnya di atas 0,05, dapat disimpulkan bahwa model regresi tidak mengandung adanya heterokedastisitas.

Tabel 3 Coefficients ${ }^{a}$

\begin{tabular}{|c|c|c|c|c|c|}
\hline \multirow[b]{2}{*}{ Model } & \multicolumn{2}{|c|}{$\begin{array}{c}\text { Unstandardized } \\
\text { Coefficients }\end{array}$} & \multirow{2}{*}{$\begin{array}{c}\begin{array}{c}\text { Standardized } \\
\text { Coefficients }\end{array} \\
\text { Beta } \\
\end{array}$} & \multirow[b]{2}{*}{$\mathrm{t}$} & \multirow[b]{2}{*}{ Sig. } \\
\hline & B & Std. Error & & & \\
\hline $1 \quad$ (Constant) & 5.810 & 4.788 & & 1.213 & .227 \\
\hline CR & .008 & .007 & .105 & 1.130 & .261 \\
\hline DER & -.905 & 1.371 & -.060 & -.660 & .511 \\
\hline Log_EPS & 1.918 & 1.878 & .097 & 1.021 & .309 \\
\hline ROA & .154 & . 101 & .149 & 1.518 & .132 \\
\hline
\end{tabular}

Sementara hasil Uji Autokorelasi ditampilkan dalam Tabel 4. Dasar pengambilan keputusan ada tidaknya autokorelasi yaitu dengan melihat tabel 
Durbin Watson, yaitu $4-\mathrm{du}<\mathrm{d}<4=4-1,788=2,212$, karena nilai $1,728<$ 2,212 maka tidak terjadi autokorelasi.

\begin{tabular}{l|c|r|r|r|r|}
\hline Model & $\mathrm{R}$ & R Square & Adjusted R Square & $\begin{array}{c}\text { Std. Error of the } \\
\text { Estimate }\end{array}$ & Durbin-Watson \\
\hline 1 & $.554^{\mathrm{a}}$ & .307 & .285 & 18.20969 & 1.728 \\
\hline
\end{tabular}
a. Predictors: (Constant), ROA, DER, CR, EPS
b. Dependent Variable: DPR

Berdasarkan analisis dengan program SPSS 16 for Windows diperoleh hasil persamaan regresi berganda sebagai berikut:

$$
\mathrm{Y}=7,664+0,052 \mathrm{CR}-0,147 \mathrm{DER}+6,644 \mathrm{EPS}+\text { 0,349ROA }
$$

Tabel 5 ANOVA

\begin{tabular}{|c|c|c|c|c|c|}
\hline Model & Sum of Squares & $\mathrm{df}$ & Mean Square & $\mathrm{F}$ & Sig. \\
\hline 1 Regression & 18629.632 & 4 & 4657.408 & 14.046 & $.000^{\mathrm{a}}$ \\
\hline Residual & 42112.271 & 127 & 331.593 & & \\
\hline Total & 60741.903 & 131 & & & \\
\hline
\end{tabular}

Pada Tabel 5 diperoleh nilai sig $=0,000<5 \%$, artinya variabel Current Ratio, Debt to Equity Ratio, Earning Per Share dan Return On Assets secara simultan berpengaruh signifikan terhadap variabel Dividend Payout Ratio pada perusahaan yang termasuk dalam Daftar Efek Syariah periode 2008-2010.

Tabel 6 Regression Coefficients ${ }^{\mathrm{a}}$

\begin{tabular}{|c|c|c|c|c|c|}
\hline \multirow[b]{2}{*}{ Model } & \multicolumn{2}{|c|}{$\begin{array}{c}\text { Unstandardized } \\
\text { Coefficients }\end{array}$} & \multirow{2}{*}{$\begin{array}{c}\begin{array}{c}\text { Standardized } \\
\text { Coefficients }\end{array} \\
\text { Beta }\end{array}$} & \multirow[b]{2}{*}{$\mathrm{T}$} & \multirow[b]{2}{*}{ Sig. } \\
\hline & B & Std. Error & & & \\
\hline $1 \quad$ (Constant) & 7.664 & 7.763 & & .987 & .325 \\
\hline CR & .052 & .011 & .374 & 4.634 & .000 \\
\hline DER & -.147 & 2.223 & -.005 & -.066 & .947 \\
\hline Log_EPS & 6.644 & 3.044 & .180 & 2.183 & .031 \\
\hline ROA & .349 & .164 & .182 & 2.126 & .035 \\
\hline
\end{tabular}

a. Dependent Variable:

DPR

Dengan $\alpha=0,05$, hasil pengujian statistik pada variabel Current Ratio, Earning Per Share dan Return on Assets berpengaruh positif signifikan terhadap 
Dividend Payout Ratio, sedangkan variabel Debt to Equity Ratio berpengaruh negatif tetapi tidak signifikan.

Koefisien determinasi parsial digunakan untuk mengetahui seberapa besar sumbangan dari masing-masing variabel bebas terhadap variabel terikat. Secara parsial kontribusi CR, DER, EPS dan ROA terhadap DPR.

Tabel 7 Coefficients ${ }^{a}$

\begin{tabular}{|c|c|c|c|c|c|c|c|c|}
\hline \multirow[b]{2}{*}{ Model } & \multicolumn{2}{|c|}{$\begin{array}{l}\text { Unstandardized } \\
\text { Coefficients }\end{array}$} & \multirow{2}{*}{$\begin{array}{c}\text { Standardized } \\
\text { Coefficients }\end{array}$} & \multirow[b]{2}{*}{$t$} & \multirow[b]{2}{*}{ Sig. } & \multicolumn{3}{|c|}{ Correlations } \\
\hline & $B$ & Std. Error & & & & Zero-order & Partial & Part \\
\hline 1 (Constant) & 7.664 & 7.763 & & .987 & .325 & & & \\
\hline CR & .052 & .011 & .374 & 4.634 & .000 & .471 & .380 & .342 \\
\hline DER & -.147 & 2.223 & -.005 & -.066 & .947 & -.213 & -.006 & -.005 \\
\hline EPS & 6.644 & 3.044 & .180 & 2.183 & .031 & .328 & .190 & .161 \\
\hline ROA & .349 & .164 & .182 & 2.126 & .035 & .385 & .185 & .157 \\
\hline
\end{tabular}

a. Dependent Variable:

DPR

Berdasarkan Tabel 7 diketahui besarnya $\mathrm{r}^{2} \mathrm{CR}$ adalah 14,44\% yang diperoleh dari koefisien korelasi parsial untuk variabel CR dikuadratkan yaitu $(0,380)^{2}$. Besarnya pengaruh DER adalah $0,0036 \%$ yang diperoleh dari koefisien korelasi parsial untuk variabel DER dikuadratkan yaitu $(-0,006)^{2}$. Besarnya pengaruh EPS adalah 3,61\% yang diperoleh dari koefisien korelasi parsial untuk variabel EPS dikuadratkan yaitu $(0,190)^{2}$. Besarnya pengaruh ROA adalah $3,42 \%$ yang diperoleh dari koefisien korelasi parsial untuk variabel ROA dikuadratkan yaitu $(0,185)^{2}$. Hal ini menunjukkan bahwa variabel $C R$ memberikan pengaruh lebih besar terhadap DPR dibandingkan variabel DER, EPS dan ROA.

Berdasarkan hasil penelitian, variabel CR berpengaruh positif signifikan terhadap DPR. Hasil penelitian ini sesuai dengan penelitian yang dilakukan oleh Anil dan Kapoor (2008) dan Wahdah (2011) yang menyatakan CR mempunyai pengaruh positif signifikan terhadap DPR, hal ini bertentangan dengan hasil penelitian Arilaha (2009), Wira (2010) dan Darminto (2008) yang menyatakan bahwa CR berpengaruh positif tidak signifikan terhadap DPR.

CR merupakan ukuran rasio likuiditas dari laporan keuangan perusahaan. Likuiditas perusahaan menunjukkan kemampuan perusahaan mendanai operasional perusahaan dan melunasi kewajiban jangka pendek, sehingga perusahaan yang memiliki likuiditas baik maka kemungkinan pembayaran dividen juga baik. Dengan adanya batasan hutang yang berbasis bunga tidak lebih dari $82 \%$, perusahaan mampu membayar hutang lancar lebih tinggi dan berpengaruh 
pada aset lancar perusahaan yang meningkat, sehingga berdampak positif pada dividen yang dibagikan. Dapat diambil kesimpulan bahwa rasio likuiditas dapat digunakan untuk memprediksi tingkat pengembalian investasi berupa dividen bagi investor pada perusahaan yang termasuk dalam DES periode 2008-2010.

Berdasarkan hasil penelitian, variabel DER berpengaruh negatif tetapi tidak signifikan terhadap DPR pada perusahaan yang termasuk dalam Daftar Efek Syariah. Hasil penelitian ini sesuai dengan penelitian yang dilakukan oleh Arilaha (2009), Marlina dan Danica (2009), Wahdah (2011), dan Sumiadji (2011) yang menyatakan bahwa DER memiliki pengaruh negatif tidak signifikan terhadap DPR, hal ini bertentangan dengan hasil penelitian Wira (2010) dan Masdupi (2012) yang menyatakan bahwa DER berpengaruh negatif signifikan terhadap DPR. Debt to Equity Ratio merupakan rasio hutang terhadap modal. Rasio ini mengukur seberapa jauh perusahaan dibiayai oleh hutang, semakin tinggi nilai rasio ini menggambarkan gejala yang kurang baik bagi perusahaan. Dengan adanya pembatasan hutang yang berbasis bunga tidak lebih dari $82 \%$ maka hutang perusahaan menjadi terkendali, sehingga investor dalam melakukan investasi tidak memandang pentingnya penggunaan hutang maupun pengembalian bunga dan pokok hutang karena investor merasa percaya terhadap pengelolaan hutang perusahaan. Hal ini disebabkan karena dividen pada tahun 2008 sampai 2010 relatif stabil, sehingga investor merasa cukup aman untuk berinvestasi tanpa melihat informasi hutang perusahaan.

Berdasarkan hasil penelitian, variabel EPS berpengaruh positif signifikan terhadap DPR pada perusahaan yang termasuk dalam Daftar Efek Syariah. Hasil penelitian ini sesuai dengan penelitian yang dilakukan oleh Imran (2011), dan Darminto (2008) yang menyatakan bahwa EPS berpengaruh positif signifikan terhadap DPR, hal ini bertentangan dengan hasil penelitian Anil dan Kapoor (2008) yang menyatakan bahwa EPS berpengaruh positif tidak signifikan terhadap DPR. Earning Per Share merupakan tingkat keuntungan bersih yang mampu diraih perusahaan dalam menjalankan operasinya. Keuntungan yang layak dibagikan sebagai dividen adalah keuntungan setelah perusahaan memenuhi seluruh kewajiban bunga dan pajak. Karena hutang yang berbasis bunga dibatasi tidak lebih dari $82 \%$, maka keuntungan bersih perusahaan akan relatif stabil, 
sehingga dividen yang diambil dari keuntungan bersih yang diperoleh perusahaan juga stabil. Dengan adanya pendapatan bunga tidak lebih dari 10\%, maka total pendapatan perusahaan akan relatif stabil, sehingga laba perusahaan yang diperoleh dari total pendapatan dikurangi total biaya juga semakin besar dan berpengaruh juga stabilnya dividen yang dibagikan.

Berdasarkan hasil penelitian, variabel ROA berpengaruh positif signifikan terhadap DPR pada perusahaan yang termasuk dalam Daftar Efek Syariah. Hasil penelitian ini sesuai dengan penelitian yang dilakukan oleh Marlina dan Danica (2009) dan Pribadi dan Sampurno (2012) yang menyatakan bahwa ROA berpengaruh positif signifikan terhadap DPR, hal ini bertentangan dengan hasil penelitian Sumiadji (2011) yang menyatakan bahwa ROA berpengaruh positif tidak signifikan terhadap DPR. Return on Assets merupakan rasio profitabilitas, di mana semakin tinggi ROA maka pertumbuhan laba akan meningkat yang memungkinkan pembagian dividen juga besar. Hal ini menunjukkan perusahaan selalu berusaha meningkatkan citra perusahaan dengan cara setiap peningkatan laba akan diikuti dengan peningkatan porsi laba yang dibagi sebagai dividen. Dengan adanya pembatasan pendapatan bunga tidak lebih dari 10\%, maka total pendapatan perusahaan tidak begitu fluktuatif dan pada akhirnya berdampak pada keuntungan dividen yang dibagikan juga stabil. Pembatasan hutang yang berbasis bunga tidak lebih dari $82 \%$ akan mempengaruhi total biaya, karena laba bersih perusahaan diperoleh dari total pendapatan dikurangi dengan total beban, sehingga laba akan cenderung stabil dan berpengaruh juga pada dividen yang dibagikan.

\section{Penutup}

Berdasarkan hasil penelitian dapat disimpulkan bahwa terdapat pengaruh variabel Current Ratio, Debt to Equity Ratio, Earning Per Share, dan Return on Assets secara simultan terhadap Dividend Payout Ratio pada perusahaan yang termasuk dalam Daftar Efek Syariah periode 2008-2010. Secara parsial variabel Current Ratio, Earning Per Share, dan Return on Assets berpengaruh positif signifikan terhadap Dividend Payout Ratio, sedangkan variabel Debt to Equity Ratio 
berpengaruh negatif tidak signifikan terhadap Dividend Payout Ratio pada perusahaan yang termasuk dalam Daftar Efek Syariah periode 2008-2010.

EPS berpengaruh positif signifikan terhadap DPR pada perusahaan yang termasuk dalam Daftar Efek Syariah. Earning Per Share merupakan tingkat keuntungan bersih yang mampu diraih perusahaan dalam menjalankan operasinya. Keuntungan yang layak dibagikan sebagai dividen adalah keuntungan setelah perusahaan memenuhi seluruh kewajiban bunga dan pajak. Adanya pembatasan hutang yang berbasis bunga tidak lebih dari $82 \%$, menyebabkan keuntungan bersih perusahaan akan relatif stabil, demikian pula dividen yang diambil dari keuntungan bersih perusahaan juga semakin stabil. Ketentuan pendapatan bunga tidak lebih dari 10\%, berdampak pada total pendapatan perusahaan akan relatif stabil, sehingga laba perusahaan yang diperoleh dari total pendapatan dikurangi total biaya juga semakin besar dan dividen yang dibagikan menjadi relatif stabilnya.

ROA berpengaruh positif signifikan terhadap DPR pada perusahaan yang termasuk dalam Daftar Efek Syariah. Return On Assets merupakan rasio profitabilitas, di mana semakin tinggi ROA maka pertumbuhan laba akan meningkat yang memungkinkan pembagian dividen juga besar. Hal ini menunjukkan perusahaan selalu berusaha meningkatkan citra perusahaan dengan cara setiap peningkatan laba akan diikuti dengan peningkatan porsi laba yang dibagi sebagai dividen. Dengan adanya pembatasan pendapatan bunga tidak lebih dari $10 \%$, maka total pendapatan perusahaan tidak begitu fluktuatif dan pada akhirnya berdampak pada keuntungan dividen yang dibagikan juga stabil. Pembatasan hutang berbasis bunga tidak lebih dari $82 \%$ berpengaruh pada laba bersih perusahaan yang diperoleh, karena total pendapatan dikurangi dengan total beban yang semakin berkurang akibat turunnya biaya bunga, sehingga laba akan cenderung stabil dan berpengaruh positif pada besarnya dividen yang dibagikan.

Bagi manajemen perusahaan, sebaiknya lebih memperhatikan aspek CR, EPS, dan ROA, karena sesuai dengan hasil penelitian ketiga variabel tersebut menjadi acuan bagi investor dalam memilih saham yang masuk dalam DES. Hal ini terjadi karena investor cenderung berkepentingan terhadap kemampuan perusahaan menghasilkan keuntungan di masa yang akan datang berupa rasio 
pembayaran dividen. Variabel DER tidak perlu menjadi perhatian utama karena dengan adanya batasan utang yang berbasis bunga tidak lebih dari 82\%, manajemen mampu mengelola utang perusahaan secara lebih baik. Bagi investor yang bermaksud ingin melakukan investasi sebaiknya memperhatikan CR, EPS, dan ROA karena berdasarkan penelitian ini ketiga rasio tersebut mempunyai pengaruh terhadap DPR. Nilai CR, EPS, dan ROA yang ditetapkan perusahaan semakin tinggi, maka semakin besar keuntungan yang akan diterima oleh investor, dan sebaiknya DER tidak perlu menjadi perhatian utama dalam menentukan dividen, karena sudah adanya batasan utang yang berbasis bunga kurang dari $82 \%$ dan total pendapatan bunga dan pendapatan tidak halal lainnya dibandingkan dengan total pendapatan usaha adalah kurang dari $10 \%$, sehingga utang perusahaan terkendali dan pendapatan perusahaan relatif stabil. Keterbatasan penelitian ini variabel independen yang digunakan hanya empat variabel yaitu CR, DER, EPS dan ROA, sehingga bagi peneliti selanjutnya dapat menggunakan variabel lain yang mempengaruhi DPR namun tidak masuk dalam model yang diuji dalam penelitian ini.

\section{Daftar Pustaka}

Anil, Kanwal and Sujata Kapoor. 2008. "Determinants of Dividend Payout Ratios-A Study of Indian Information Technology Sector”. International Research Journal of Finance and Economics. India.

Brigham dan Houston. 2006. Dasar-dasar Manajemen Keuangan Buku 2. Jakarta: Salemba Empat.

Darminto. 2008. "Pengaruh Profitabilitas, Likuiditas, Struktur Modal dan Struktur Kepemilikan Saham Terhadap Kebijakan Dividen”. Jurnal Ilmu-ilmu Sosial, Volume 20 No. 2 Hal 87-97. Malang: Universitas Brawijaya.

Faulkender, Michael. Milbourn, Anjan Thakor. Todd. Does Corporate Performance Determine Capital Structure and Dividend Policy?, March 9, 2006.

Imran, Khasif. 2011. "Determinants of Dividend Payout Policy: A Case of Pakistan Engineering Sector". The Romanian Economic Journal, No. 41 Hal 47-59. Pakistan: University of Karachi. 
Marlina, Lisa dan Clara Danica. 2009. “Analisis Pengaruh Cash Position, Debt to Equity Ratio, dan Return On Assets Terhadap Dividend Payout Ratio". Jurnal Manajemen Bisnis, Volume 2 No. 1 Hal 1-6. Universitas Sumatra Utara.

Masdupi, Erni. 2012. "Pengaruh Insider Ownership, Struktur Modal, dan Pertumbuhan Perusahaan Terhadap Kebijakan Dividen Perusahaan Syariah yang Terdaftar Di Bursa Efek Indonesia”. Jurnal Economac, Volume 12 No. 1 Hal 9-14. Universitas Negeri Padang.

Pribadi, Anggit Satria dan R. Djoko Sampurno. 2012. "Analisis Pengaruh Cash Position, Firm Size, Growth Opportunity, Ownership, dan Return On Asset Terhadap Dividend Payout Ratio". Journal of Management, Volume 1 No. 1 Hal 212-211. Semarang: Universitas Diponegoro.

Riyanto, Bambang. 2001. "Dasar-dasar Pembelajaran Perusahaan Edisi Keempat”. Yogyakarta: BPFE.

Sartono, Agus. 2001. "Manajemen Keuangan Teori dan Aplikasi Edisi Keempat”. Yogyakarta: BPFE.

Wahdah, Rofiqoh. 2011. “Analisis Faktor-faktor yang Mempengaruhi Tingkat Pengembalian Investasi pada Perusahaan Manufaktur Di Bursa Efek Indonesia”. Jurnal Socioscientie, Volume 3 No. 2. Hal 309-320. Banjarmasin: STIE Indonesia.

Wira, Variyetmi. 2010. "Faktor yang Mempengaruhi Pengembalian Investasi pada Equity Securities pada Perusahaan Manufaktur Di Indonesia”. Jurnal Akuntansi dan Manajemen, Volume 5 No. 1. Hal 87-99. Sumatera Utara: Politeknik Negeri Padang. 